\title{
SOSIALISASI DAN PENDAMPINGAN SADAR ARSIP DI LINGKUNGAN UNIVERSITAS WIRARAJA
}

\author{
Roos Yuliastina ${ }^{1}$ Isyanto $^{2}$, Nur Inna Alfiyah ${ }^{3}$ \\ ${ }^{1,3)}$ Dosen Fakultas Ilmu Sosial dan Ilmu Politik Universitas Wiraraja \\ ${ }^{2)}$ Dosen Fakultas Ekonomi dan Bisnis Universitas Wiraraja \\ Email: ${ }^{1)}$ yuliastina07@ gmail.com, ${ }^{2)}$ isyanto@ wiraraja.ac.id, ${ }^{3)}$ fifi.alfiyah@yahoo.com
}

\begin{abstract}
ABSTRAK
Kurangnya kesadaran arsip di kalangan masyarakat khususnya di suatu lembaga maupun instansi-instansi merupakan salah satu gambaran bahwa selama ini arsip dianggap kurang penting. Sedangkan arsip merupakanrekaman kegiatan atau peristiwa dalam berbagai bentuk dan media sesuai dengan perkembangan teknologi informasi dan komunikasi yang dibuat dan diterima oleh lembaga negara, pemerintah daerah, lembaga pendidikan, perusahaan, organisasi politik, organisasi kemasyarakatan, dan perseorangan dalam pelaksanaan kehidupan bermasyarakat, berbangsa dan bernegara. (UU43/2009, psl 1 angka 2).

Dalam program kegiatan yang dilakukan dimulai dari tahap persiapan tahap sosialisasi dan pengenalan mengenai pentingnya sadar arsip tahap pengimplementasian tahap pendampingan dan terakhir yaitu tahap evaluasi. Dari beberapa tahapan tersebut telah mampu membantu pencapaian tujuan lebih meningkatkan kesadaran mengenai pentingnya arsip bagi seluruh karyawan serta membantu pengelolaan arsip di setiap fakultas di Universitas Wiraraja.
\end{abstract}

Kata Kunci: Sosialisasi, Pendampingan, Kearsipan

\section{PENDAHULUAN}

Universitas Wiraraja (UNIJA) yang merupakan salah satu instansi perguruan tinggi swasta, dokumen-dokumen penting baik yang menyangkut penyelenggaran administratif universitas, data-data dosen, karyawan dan mahasiswa, legalitas keberadaan universitas, serta kegiatan atau peristiwa lain yang bersangkutan dengan Universitas Wiraraja, sistem pengelolaan arsip masih kurang efektif dan efisien, baik dalam segi tempat penyimpanan arsip, penyusunan arsip dan penataan arsip.

Berdasarkan hal tersebut, maka itulah yang mendasari kegiatan pengabdian dengan tema sardar arsip di lingkungan Universitas Wiraraja untuk membenahi dan melakukan perbaikan mengenai arsip dalam segi penataan, penyusunan dan penyimpanan dilingkup internal universitas terlebih dahulu sebelum mengimplementasikan kepada masyarakat luas. Dalam lingkup internal universitas, kami melibatkan secara langsung Kepala Tata Usaha (KTU) beserta seorang staf dari tujuh fakultas Unija, yaitu Fakultas Ilmu Sosial Dan Ilmu Politik, Fakultas Ekonomi, Fakultas Hukum, Fakultas Teknik, Fakultas Kesehatan, Fakultas Pertanian, Fakultas Keguruan Ilmu Pendidikan, dan melibatkan seorang staf bagian umum di Biro Administrasi Umum (BAU). Bagian-bagian tersebut menjadi sasaran utama kami untuk mengimplementasikan perbaikan sistem pengelolaan arsip dalam segi penataan, penyususan dan penyimpanan arsip, karena mereka yang mengurus dan terlibat secara langsung dengan arsip.

Untuk menjadikan Universitas Wiraraja yang lebih baik dalam segi pengelolaan dan penyimpanan arsip, kami harus mampu melakukan hubungan kerjasama yang baik dengan semua komponen yang berada di dalam lingkup universitas, baik dari pimpinan teratas universitas, pimpinan setiap fakultas, 
para karyawan maupun dari para mahasiswa Universitas Wiraraja.

Melihat seberapa pentingnya arti arsip yang sesungguhnya, maka meningkatkan kesadaran dan kepedulian dari perseorangan adalah kunci utama untuk menyelamatkan arsip. Karena tanpa kita sadari, sejak lahir hingga meninggal dunia akan membutuhkan keberadaan arsip. Sedangkan untuk suatu instansi atau lembaga seperti Universitas Wiraraja Sumenep, arsip itu sendiri dapat dikatakan sebagai urat nadi, karena tanpa adanya arsip maka penyelenggaran program kerja yang telah ditentukan tidak dapat beroperasional dengan baik.

Adapun permasalahan utama yang ingin dislesaikan melalui kegiatan pengabdian ini diantaranya: (1) karena masih rendahnya kesadaran staf bagian kearsipan Universitas Wiraraja akan pentingnya pengarsipan yang baik, (2) masih kurangnya keterampilan SDM tenaga pendidik dalam pengelolaan arsip dengan efektif dan efisien.

Luaran yang diharapkan dari kegiatan sosialisasi dan pendampingan ini diantarnya; (1) meningkatkan kesadaran dan kepedulian dari para tenaga pendidik seperti staf KTU danstaf BAU di Universitas Wiraraja untuk lebih memperhatikan tentang tata cara penyimpanan dan pengelolaan arsip; (2) menambah keterampilan dan pengetahuan tenaga pendidik dari para staf KTU dan staf BAU Universitas Wiraraja dalam meningkatkan kesadaran arsip agar dapat terjaga secara dinamis dan berkesinambungan.

\section{METODE}

Metode kegiatan dalam pengabdian ini, menggunakan beberapa tahapan. Diantaranya tahapan pengurusan ijin, kegiatan sosialisasi,tahap pelaksanaan, pendampingan, dan evaluasi. Berikut rincian langkah-langkah kegiatan yang dilakukan: a. Tahap Pengurusan Ijin

Mengurus semua keperluan perijinan yang diperlukan agar nantinya dalam pelaksanaan kegiatan bisa berjalan dengan baik dan lancar.

b. Tahap Pengenalan atau Sosialisasi

Pada tahap pengenalan atau sosialisas memberikan gambaran secara umum kepada Kepala Tata Usaha beserta seorang staf dari tujuh fakultas dan ditambah seorang staf bagian umum di Biro Administrasi Umum (BAU) tentang pelaksanaan kegiatan kami. Sosialisasi mengenai penting sadar arsip juga kami lakukan dengan melibatkan radio FM Unija yang merupakan salah satu sumber informasi di lingkup universitas untuk memberitahukan kegiatan yang kami lakukan serta memberikan pula gambarangambaran mengenai arsip bagi masyarakat di luar universitas. Selain itu, dengan adanya majalah yang memuat informasi mengenai universitas, kami juga bekerjasama dengan pihak tersebut sebagai salah satu awal untuk mempromosikan bahwa di Universitas Wiraraja sudah mulai sadar arsip.

c. Tahapan Pelaksanaan dan pendampingan

1) Mengumpulkan kepala tatausaha beserta seorang staf dari tujuh fakultas dan seorang staf bagian umum di Biro Administrasi Umum (BAU). Tahap pelaksanaan pertama yang tim kami lakukan yaitu guna menjelaskan mengenai arsip itu sendiri dan pentingnya menata atau mengelolah arsip. Pelaksanaan pertama ini yaitu dengan dibukanya forum diskusi interaktif antara narasumber dengan seluruh staf KTU dan staf BAU.

2) Proses Implementasi

Disini kami mulai melalukan survei di setiap fakultas dan BAU, untuk 
menanyakan kendala atau hambatan atau keluhan yang dialami oleh para staf selama mereka mengurus kearsipan, sehubungan dengan hasil sosialisasi yang telah kami lakukan.

3) Pendampingan dari Implementasi Setelah melakukan proses implementasi yaitu survei di setiap fakultas dan BAU, kami tim mendampingi setiap fakultas dan BAU untuk membantu menyelesaikan kendala-kendala yang mereka alami seperti penataan dan penyusunan arsip, membantu menseleksi antara arsip yang penting dan arsip yang tidak penting. Mengenai ruang kerja yang mereka rasa kurang nyaman disebabkan karena ruang kerja yang sempit serta sarana dan prasarana penyimpanan arsip yang kurang memadai, hal itu tidak dapat kami selesaikan secara penuh karena masih dalam tahap pelaporan kepada atasan yakni rektor Universitas Wiraraja Sumenep, tetapi dengan penataan arsip yang rapi di ruang kerja yang minim telah sedikit memberikan kenyaman bagi para staf dalam melaksanakan pekerjaannya. Pada saat melakukan pendampingan, kami membagi tim yaitu satu orang memiliki tanggungjawab pendampingan dua fakultas.

\section{d. Evaluasi}

Tim FKMSA melakukan monitoring untuk masing-masing fakultas dan BAU dari setelah kami melakukan pendampingan di setiap fakultas dan BAU, apakah ada yang sudah menerapkan dan melakukan proses ulang perbaikan pengarsipan, dengan baik dan benar, apakah penataan dan penyusunan arsip tetap tersusun dengan rapi di ruang kerja para staf. Setelah itu tim membagi anggota yang sudah paham untuk saling berbagi cara dengan peserta yang lain yang belum paham sehingga kemampuan mereka rata. Dan tim memberikan stiker serta penghargaan berupa cindramata bagi fakultas atau ruangan yang termasuk dalam golongan "sadar dan memahami akan pentingnya arsip".

\section{HASIL DAN PEMBAHASAN}

Sosialisasi dan penyuluhan ini tidak hanya kami lakukan dalam bentuk forum diskusi interaktif antara narasumber yang kami datangkan dengan para staf KTU dan staf BAU, tetapi dengan memanfaatkan radio FM Unija yang merupakan salah satu sumber informasi mengenai lingkup universitas yang frekuensinya menyeluruh di kabupaten Sumenep, sehingga tidak hanya masyarakat internal universitas yang dapat mendengar, tetapi masyarakat secara lebih luas. Kami Tim FKMSA Universitas Wiraraja mendapat kesempatan untuk menjadi narasumber di radio FM Unija, dan pada saat itulah waktu dan kesempatan bagus bagi kami untuk mempromosikan sekaligus lebih memberikan pemahaman kepada masyarakat agar lebih sadar arsip, bisa melestarikan dan menyelamatkan arsip dengan baik secara efektif dan efisien.

Berdasarkan kegiatan sosialisasi dan pendampingan dapat ditemukan dua masalah utama yang menjadi faktor penghambat dalam penyelamatan arsip di lingkungan Universitas Wiraraja, diantaranya; (1) Ketentuan umur arsip yang dihimbau oleh BAU Universitas Wiraraja Sumenep tidak diterapkan secara penuh di setiap fakultas, disebabkan oleh adanya ketentuan-ketentuan tersendiri dari masing-masing fakultas, sehingga ada beberapa fakultas yang masih menyimpan 
arsip meskipun telah melebihi batas ketentuan umur yang telah ditentukan. (2) Ruang kerja yang sempit serta tempat penyimpanan arsip yang kurang efektif dan kurang memadai di beberapa fakultas.

Menyikapi permasalahan di atas, maka tim pelaksana pengabdian berupaya semaksimal mungkin untuk mencari solusi yang tepat dari permasalahan di atas, sehingga kami mengambil langkah-langkah sebagai berikut:

a. Tim menyesuaikan waktu dengan para staf KTU dan staf BAU di Universitas agar bisa menanyakan serta mendampingi untuk kegiatan implementasi. Kami juga mengambil hari libur kerja seperti hari sabtu dan minggu untuk memperbaiki apa yang kurang dan apa yang dibutuhkan di meja staf KTU dan staf BAU, namun sebelumnya kami harus mengadakan perjanjian.

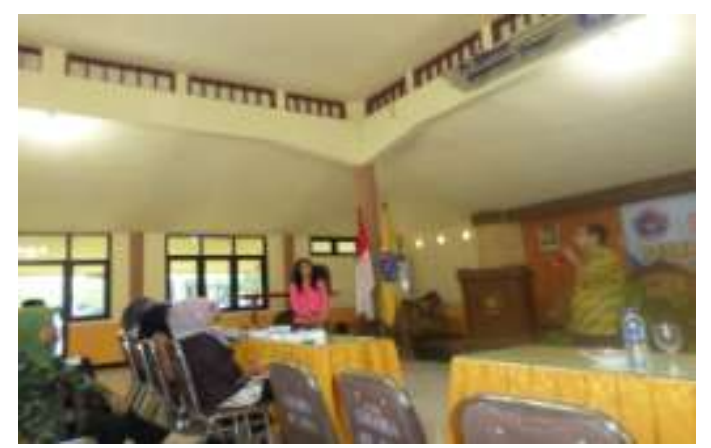

Gambar 1. Kegiatan Seminar Sadar Arsip di lingkungan Universitas Wiraraja

b. Kemudian tim mendampingi para karyawan untuk penataan dan penyesuaian arsip yang ada. Mulai dari surat masuk, surat keluar, ATK yang diperlukan, tempat KRS dan KHS, dan membantu menseleksi dokumen yang masih dibutuhkan dengan yang sudah tidak digunakan di tiap fakultas sesuai dengan himbauan BAU Universitas Wiraraja tentang umur penyimpanan dokumen. c. Tim pengabdian sedikit melakukan perubahan tempat kerja dari para staf KTU agar dengan ruang kerja yang minim, mereka bisa melaksanakan pekerjaannya dengan efektif dan efisien. Dan pada saat kami melakukan pendampingan, para staf KTU merasa tempat kerjanya lebih nyaman dari yang sebelumnya. Serta kami membantu proses penataan arsip yang ada di ruang kerja staf KTU sehingga tertata lebih rapi dan lebih efisien.

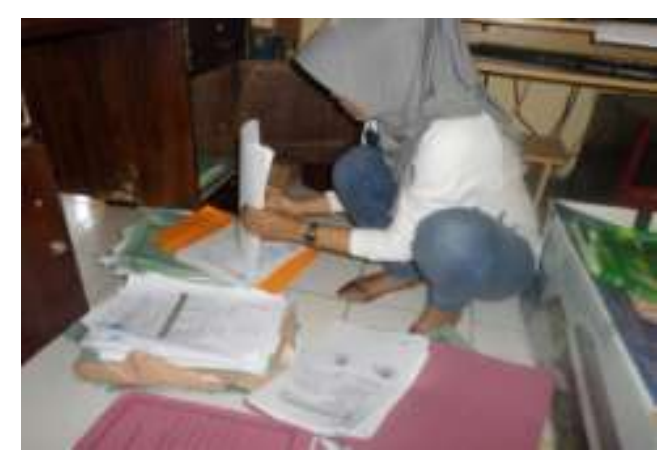

Gambar 2. Kegiatan pendampingan sadar arsip di Fakultas Universitas Wiraraja

\section{KESIMPULAN}

Berdasarkan hasil kegiatan yang dilakukan selama 3 bulan Universitas Wiraraja, terdapat beberapa masalah kearsipan yang perlu dibenahi, yaitu adanya tumpukan-tumpukan dokumen disekitar tempat kerja, penyusunan dan penataan arsip yang kurang rapi, serta kurangnya sarana dan prasarana untuk penyimpanan arsip. Setelah kami mengimplementasikan dan melakukan pendampingan secara langsung kepada tiap fakultas serta BAU, mereka memberikan respon yang baik dengan memperlihatkan kepuasan atas apa yang telah kami lakukan selama kegiatan berlangsung. Penataan arsip yang lebih baik dan lebih rapi, tempat kerja yang lebih nyaman sehingga secara langsung berdampak positif pula pada kenyamanan kerja dari para staf, hal itu yang menyebabkan mereka puas dengan apa yang telah kami lakukan 
Respon positif dari para staf KTU dan staf BAU Universitas Wiraraja atas kegiatan yang kami lakukan ini, menjadi salah satu pendorong tercapainya tujuan dari kegiatan yang kami lakukan, yaitu dimana kami berharap adanya peningkatan ke arah yang lebih baik mengenai tata cara pengelolaan arsip, penyimpanan dan penataan arsip, sehingga program kerja yang terdapat di universitas dapat dilaksanakan dengan baik secara efektif dan efisien. Karena apabila ada beberapa dokumen penting atau dokumen vital universitas yang hilang maka hal itu akan menghambat proses kerja di bagianbagian lain yang bersangkutan sehingga akan berdampak terhadap proses pencapaian tujuan dari universitas itu sendiri. Hal itu membuktikan bahwa mereka memiliki keinginan untuk memperbaiki produktivitas kinerjanya yang secara tidak langsung hal itu telah sedikit meningkatkan kesadaran dan kepedulian para karyawan atas arti pentingnya arsip.

\section{DAFTAR PUSTAKA}

$$
\begin{array}{ccr}
\text { Buku Pedoman } & \text { Peraturan } & \text { Pemerintah } \\
\text { Republik } & \text { Indoenesia } & \text { Tentang } \\
\text { Kerasipan tahun 2009. } &
\end{array}
$$

